\title{
Case Report \\ Long-Term Outcomes in a Family with Nephrogenic Syndrome of Inappropriate Antidiuresis
}

\author{
Yoon Hi Cho, ${ }^{1}$ Stephen Gitelman, ${ }^{2}$ Stephen Rosenthal, ${ }^{2}$ and Geoffrey Ambler ${ }^{1}$ \\ ${ }^{1}$ Institute of Endocrinology and Diabetes, The Children's Hospital at Westmead, Sydney, NSW 2145, Australia \\ ${ }^{2}$ Department of Pediatrics, Division of Endocrinology, University of California at San Francisco, San Francisco, CA 94143, USA
}

Correspondence should be addressed to Geoffrey Ambler, geoffa@chw.edu.au

Received 28 July 2009; Accepted 2 December 2009

Recommended by Mohamad Maghnie

We report a familial case of the nephrogenic syndrome of inappropriate antidiuresis (NSIAD), including 30-year followup data on two patients. The proband and one maternal uncle presented in their infancy with severe recurrent hyponatremia, and clinical pictures consistent with the syndrome of inappropriate antidiuretic hormone (SIADH) in the absence of an elevated ADH level. They were both confirmed to be hemizygous for the R137C mutation on the V2R gene (AVPR2), the same locus of the gain of function mutation demonstrated in the original reports of this condition. The proband's mother was identified as an asymptomatic carrier of this X-linked condition. Our case describes a favourable long-term outcome for NSIAD, in particular, successful treatment with oral urea during the infancy period, and with self-regulated precautions on fluid intake into adult life.

Copyright ( 2009 Yoon Hi Cho et al. This is an open access article distributed under the Creative Commons Attribution License, which permits unrestricted use, distribution, and reproduction in any medium, provided the original work is properly cited.

\section{Case Description}

1.1. Subject A: Index Case. An eight-week-old male infant presented to a general hospital, after 5 hours of being unsettled and vomiting, and a one-week history of cough and rhinorrhoea. Birthweight was $3660 \mathrm{~g}$ at term gestation, and he had previously been feeding well and gaining weight. His parents were nonconsanguineous, Portuguese and Caucasian Australian background. There was a family history of two maternal uncles who had a history of hyponatraemia of uncertain aetiology. One had been diagnosed with SIADH in his infancy and remained on a fluid restriction into adulthood. On examination, this infant had a viral rash and mild respiratory distress and scattered wheeze. He was clinically euvolaemic and not hyperpigmented. He had normal external male genitalia. Chest X-ray did not show focal pathology, but nasopharyngeal aspirate was positive for Moraxella catarrhalis and he was treated with oral amoxicillin. Blood tests revealed sodium $120 \mathrm{mmol} / \mathrm{L}$ (reference range 135-145), potassium $4.8 \mathrm{mmol} / \mathrm{L}$ (3.5-5.5), urea $1.9 \mathrm{mmol} / \mathrm{L}(2.0-6.7)$, creatinine $<20 \mathrm{umol} / \mathrm{L}(20-45)$, glucose $5.5 \mathrm{mmol} / \mathrm{L}$ (3.5-5.5), and osmolality $255 \mathrm{mM} / \mathrm{kg}$ (265295). Random adrenocorticotrophic hormone (ACTH) level was normal $7.3 \mathrm{pmol} / \mathrm{L}(2.0-10.0)$. Sodium chloride $(\mathrm{NaCl})$ supplementation $16 \mathrm{mmol} / \mathrm{kg} /$ day was divided into his feeds, and he was transferred to our centre.

On admission, serum $\mathrm{Na}$ remained low, $129 \mathrm{mmol} / \mathrm{L}$, with osmolality $260 \mathrm{mM} / \mathrm{kg}$ and paired urine $\mathrm{Na}<10$ $\mathrm{mmol} / \mathrm{L}$ and osmolality $506 \mathrm{mM} / \mathrm{kg}$. Antidiuretic hormone $(\mathrm{ADH})$ level $<0.6 \mathrm{pmol} / \mathrm{L}(0.1-7.0)$ and plasma renin activity (PRA) $<32 \mathrm{fM} / \mathrm{s} \quad(1070-2930)$ were both suppressed below the reference range. Aldosterone was $440 \mathrm{pmol} / \mathrm{L}$ (80-1040). Short Synacthen test demonstrated a normal cortisol response, rising from baseline $130 \mathrm{nmol} / \mathrm{L}$ to peak $1393 \mathrm{nmol} / \mathrm{L}$ at 60 minutes, and normal stimulated 17hydroxyprogesterone to cortisol ratios. Baseline ACTH level was confirmed to be normal. Renal ultrasound visualised normal kidneys and bladder, with both testes present within the scrotum. The above investigations therefore excluded adrenal hormonal and renal structural abnormalities. Sodium improved to $131 \mathrm{mmol} / \mathrm{L}$, and he was discharged home on oral salt supplementation.

He represented with hyponatraemia, vomiting, and feed refusal, leading to two additional hospital admissions within the next two weeks. On both occasions, he appeared well and euvolemic. Despite low Na $125 \mathrm{mmol} / \mathrm{L}$ and serum osmolality $255 \mathrm{mM} / \mathrm{L}$, he now demonstrated an inappropriately high urine sodium $104 \mathrm{mmol} / \mathrm{L}$ and osmolality $335 \mathrm{mM} / \mathrm{L}$. 
TABLE 1: Monitoring urea therapy.

\begin{tabular}{|c|c|c|c|c|c|c|c|c|}
\hline Age (months) & $\begin{array}{l}3 \text { (pre-urea } \\
\text { therapy) }\end{array}$ & 4 & $\begin{array}{l}6 \text { (intercur- } \\
\text { rent illness) }\end{array}$ & 10 & 18 & 19 & 21 & 33 \\
\hline $\begin{array}{l}\text { Serum } \mathrm{Na} \\
(135-145 \\
\mathrm{mmol} / \mathrm{L})\end{array}$ & 124 & 139 & 118 & 136 & 140 & 137 & 138 & 139 \\
\hline $\begin{array}{l}\text { Serum urea } \\
(2.0-6.7 \\
\mathrm{mmol} / \mathrm{L})\end{array}$ & 1.8 & 10.2 & 12.6 & 9.9 & 9.4 & 6.1 & 5.1 & 3.1 \\
\hline $\begin{array}{l}\mathrm{ADH}(0.1- \\
7.0 \mathrm{pmol} / \mathrm{L})\end{array}$ & 0.6 & - & - & - & - & - & - & 1.2 \\
\hline Urea dose & $\begin{array}{l}1.5 \mathrm{~g} / \mathrm{kg} / \mathrm{day}, \\
6 \text { divided } \\
\text { doses }\end{array}$ & $\begin{array}{l}2 \mathrm{~g} / \mathrm{kg} / \mathrm{day}, 4 \\
\text { divided doses }\end{array}$ & $\begin{array}{l}2 \mathrm{~g} / \mathrm{kg} / \mathrm{day}, 4 \\
\text { divided doses }\end{array}$ & $\begin{array}{l}1.9 \mathrm{~g} / \mathrm{kg} / \mathrm{day}, 4 \\
\text { divided doses }\end{array}$ & $\begin{array}{l}1.2 \mathrm{~g} / \mathrm{kg} / \mathrm{day}, \\
\text { Weaning doses }\end{array}$ & Ceased & Nil & Nil \\
\hline $\begin{array}{l}\text { Fluid } \\
\text { restriction }\end{array}$ & $70 \mathrm{~mL} / \mathrm{kg} /$ day & $50 \mathrm{~mL} / \mathrm{kg} /$ day & $50 \mathrm{~mL} / \mathrm{kg} /$ day & $\begin{array}{l}65 \mathrm{~mL} / \mathrm{kg} / \text { day } \\
(650 \mathrm{~mL} / \text { day })\end{array}$ & $\begin{array}{l}80 \mathrm{~mL} / \mathrm{kg} / \text { day } \\
(1000 \mathrm{~mL} / \text { day })\end{array}$ & $\begin{array}{l}80 \mathrm{~mL} / \mathrm{kg} / \text { day } \\
(1000 \mathrm{~mL} / \text { day })\end{array}$ & $\begin{array}{l}90 \mathrm{~mL} / \mathrm{kg} / \text { day } \\
(1200 \mathrm{~mL} / \text { day })\end{array}$ & $\begin{array}{l}75 \mathrm{~mL} / \mathrm{kg} / \text { day } \\
(1200 \mathrm{~mL} / \text { day }) \text {, } \\
\text { increased to } \\
94 \mathrm{~mL} / \mathrm{kg} / \text { day } \\
(1500 \mathrm{~mL} / \text { day })\end{array}$ \\
\hline
\end{tabular}

Repeat $\mathrm{ADH}$ level was detectable but low $(0.6 \mathrm{pmol} / \mathrm{L})$; aldosterone was $497 \mathrm{pmol} / \mathrm{L}$ and PRA remained suppressed. Sodium level responded to a fluid restriction of $60 \mathrm{~mL} / \mathrm{kg} /$ day and intravenous $0.9 \%$ saline infusion, rising to nearnormal levels after 48 hours. When fluids were liberalised to oral feeds, serum sodium declined from $138 \mathrm{mmol} / \mathrm{L}$ to $124 \mathrm{mmol} / \mathrm{L}$, even whilst on $\mathrm{NaCl}$ supplementation of $5 \mathrm{mmol} / \mathrm{kg} /$ day. Thyroid function tests were normal. Chest $\mathrm{X}$-ray now showed subsegmental collapse in the right upper zone and consolidation in the right middle zone. Throat suction swab grew Staphylococcus aureus, which was treated with a two-week course of oral flucloxcillin. Newborn screening, extended genetic analysis for common cystic fibrosis transmembrane conductance regulator (CFTR) mutations, and a sweat test excluded cystic fibrosis as a cause for salt loss and respiratory symptoms. Abdominal ultrasound and surgical consultations were sought to exclude pyloric stenosis. Magnetic resonance imaging of the brain was normal.

This clinical picture of SIADH despite low to normal $\mathrm{ADH}$ levels raised the possibility of a receptor or postreceptor defect. A provisional diagnosis of the recently described "nephrogenic syndrome of inappropriate antidiuresis" was made and this was later confirmed by genetic studies (see below). He was commenced on oral urea at $1.5 \mathrm{~g} / \mathrm{kg} /$ day in 6 divided doses and maintained on a fluid restriction of $70 \mathrm{ml} / \mathrm{kg} /$ day. Feeds were concentrated to provide more calories. The dose of urea was gradually increased and well tolerated at a target dose of $2 \mathrm{~g} / \mathrm{kg} /$ day, without any evidence of dehydration. Sodium in midnormal range and slightly elevated urea levels were indicators of compliance (Table 1). By 6 months of age, the infant was on a predominantly solid diet and has since remained on a modest fluid restriction. Urea was able to be weaned and ceased by 19 months of age. He demonstrated appropriate developmental progress and growth.
1.2. Subject B: Maternal Uncle 1 of Index Case. Medical records of the maternal uncle of Patient A were reviewed.

Subject B had presented to our hospital 29 years earlier with a generalized tonic clonic seizure at age of 22 months. There was a 3-day history of ataxia and lack of interest in feeding preceding this event. He was born at term and had an uneventful neonatal history. He was noted by his mother to be usually reluctant to drink, and on the night before the presentation, he was given additional fluids to try to settle him. There was evidence of mild delay in gross motor development, crawling at 13 months, and walking unaided at 17 months. He was able to speak 20 words by 19 months of age. On examination, he was afebrile and hypertensive with BP 130/90 but otherwise had normal examination. Weight was $10 \mathrm{~kg}$ (3rd percentile) and head circumference was $47.5 \mathrm{~cm}$ (50th percentile).

Serum sodium on admission was $124 \mathrm{mmol} / \mathrm{L}$ with blood glucose level $2.2 \mathrm{mmol} / \mathrm{L}$. Other electrolytes and full blood counts were normal. Serum osmolality was $265 \mathrm{mmol} / \mathrm{kg}$, with urine osmolality inappropriately concentrated at $950 \mathrm{mmol} / \mathrm{kg}$. He sustained another convulsion during the hospital admission. The diagnosis at the time of discharge was seizures of unknown aetiology, with concurrent SIADH. He was maintained on oral phenobarbitone.

Followup blood tests two days later showed severe hyponatraemia of $112 \mathrm{mmol} / \mathrm{L}$. He was slightly irritable and ataxic, but otherwise displayed normal examination. Fluid restriction was commenced at $500 \mathrm{~mL} /$ day. Extensive investigations, including a brain scan, were unremarkable. Synacthen stimulation test showed a normal cortisol response. A water-loading test showed serum sodium falling to $129 \mathrm{mmol}$ at 6 hours, with osmolality of $287 \mathrm{mmol} / \mathrm{kg}$, and high urine sodium $199 \mathrm{mmol} / \mathrm{L}$ and osmolality $1092 \mathrm{mmol} / \mathrm{kg}$.

The most likely diagnosis was considered to be SIADH, but serum $\mathrm{ADH}$ estimation was found to be low at $1.43 \mathrm{pg} / \mathrm{mL}$ (mean adult level $6.5 \mathrm{pg} / \mathrm{mL}$ ). This was at a time 
(1977) when this assay had just become available in Australia, so there were concerns about accuracy. At age of 31 years, Patient B is working as an accountant and had remained generally well throughout his childhood with spontaneous limitation of fluid intake. He knew that he needed to restrict free water intake in order to maintain his sense of well being but was not aware of his underlying diagnosis. On one notable occasion he had taken an extended flight and drank extra water and no alcohol as suggested by the flight crew. At his destination he was described to be in a confused state which resolved after several hours, but of which he retained no memory.

1.3. Subject C. Patient $C$ was the other maternal uncle, currently a manager in the automotive industry. He and his family were unaware of any problems in childhood, although as an adult he had had several episodes of being unwell and was found to have a mildly low sodium at the time, although had not been further investigated. He was aware that he had a low thirst and low fluid intake compared to others.

1.4. Family Study. Consent was obtained from the family members of the index case for genetic testing of the mutation described by the original case report by Feldman et al. Samples were sent to Quest Diagnostics (R. Fenwick, Nichols Institute, CA, USA) for DNA analysis. After PCR amplification of the AVPR2 gene, mutations were detected by DNA sequence analysis of all protein coding regions of the gene plus flanking sequences [1]. The index case (Patient A) was found to be positive for the R137C mutation.

His mother was asymptomatic with normal serum sodium $145 \mathrm{mmol} / \mathrm{L}$. She was found to be a heterozygote carrier for the R137C mutation.

Maternal uncle 1 (subject B) had current baseline hyponatraemia without symptoms, with $\mathrm{Na} 131 \mathrm{mmol} / \mathrm{L}$, serum osmolality $264 \mathrm{mM} / \mathrm{kg}$, urine osmolality $851 \mathrm{mM} / \mathrm{kg}$, and $\mathrm{ADH}<0.6 \mathrm{pmol} / \mathrm{L}$. He was found to be positive for the R137C mutation.

Maternal uncle 2 (subject C) had baseline $\mathrm{Na} 133$ $\mathrm{mmol} / \mathrm{L}$, serum osmolality $279 \mathrm{mM} / \mathrm{kg}$, and urine osmolality $946 \mathrm{mM} / \mathrm{kg}$. ADH was $1.36 \mathrm{pg} / \mathrm{mL}(<1 \mathrm{pg} / \mathrm{mL})$, considered high for the serum osmolality. He was also found to be positive for the R137C mutation.

Maternal aunt was asymptomatic and 6 months pregnant at the time of testing. Laboratory studies were normal, and she was not a carrier of the mutation.

\section{Literature Review and Discussion}

In 2005, Feldman et al. [1] described a clinical condition resulting from a gain of function of the vasopressin receptor (V2R gene), which was named nephrogenic syndrome of inappropriate antidiuresis. This can be conceptualised as the opposite phenomena to nephrogenic diabetes insipidus, which results from a loss of function of the vasopressin receptor. In the original article, two unrelated male infants were found to have the clinical picture of SIADH in the absence of an elevated $\mathrm{ADH}$. In patient 1 , the arginine on codon 137 was substituted with cysteine (R137C), and his mother was heterozygous for the R137C mutation, suggesting an $\mathrm{X}$-linked inheritance. In patient 2 , arginine was substituted with leucine (R137L), with no mutation found in his mother, likely as a result of spontaneous mutation. Functional analysis confirmed constitutive activation of this receptor.

Over 200 different mutations on the V2R gene have been found to cause nephrogenic diabetes insipidis [2]. It has therefore been postulated that a genetic heterogeneity may exist in NSIAD. To date, however, the R137C has been the mutation predominantly implicated, apart from one case of an R137L mutation. There may also be other parts of the signalling pathway which are yet not clearly understood.

Mutations in the V2R gene may not explain all cases of NSIAD. In 2001, Tanaka et al. described a threegeneration family to have an "SIADH-like condition" with undetectable ADH levels [3]. The 12-month-old proband presented with persisting hyponatraemia following a febrile seizure. The 32-year-old mother and 59-year-old maternal grandmother self-restricted fluid intake and had low to low normal baseline serum sodium. A water-loading test on all three subjects showed impaired water excretion. Urine aquaporin-2 (AQP2) concentration, which is a marker of AVP dependent AQP2 levels, was normal. The plasma AVP was undetectable in the proband and mother (grandmother refused sampling). A "gain of function" mutation involving the AVP receptor or aquaporin channel was considered but DNA sequencing for both AVPR2 and AQP2 was found to be normal. Another interesting aspect of this case series is that all three affected members were females. Although Xlinked conditions can be partially expressed in a female, or fully expressed in the presence of Lyonisation or $45 \mathrm{XO}$, this familial pattern can also be consistent with autosomal dominant and suggests that other genetic causes or another level of constitutive activation may be involved [3].

Another report identified the activating missense mutation on R137C in three hemizygous males and four heterozygous females of a large family pedigree [4]. It highlighted several important aspects of this condition: presence in adulthood and presence of symptoms in both males and females. All except one female, subsequently found to have skewed X inactivation, had spontaneous hyponatraemia or an abnormal water-loading test.

The current reports of NSIAD to date are primarily infants who have had recurrent presentations with hyponatraemia and often seizures. The diagnosis may be elusive and often requires extensive investigations to exclude underlying central or pulmonary pathology. There may be concurrent clinical factors contributing to the hyponatraemia, such as the intercurrent respiratory illness in our patient. Precipitants may include excessive bottle feeding and, in adults, prolonged exercise [5] or hot days with extra fluid intake, alcohol binges, and overriding one's own protective thirst mechanisms.

The condition can also present in adulthood and should be suspected in a patient with a clinical diagnosis of SIADH, unresponsive to usual medications used in chronic SIADH, including the new V2R antagonist tolvaptan [4]. 
Developmentally, the neonate and infant seem to be at high risk for hyponatremia with NSIAD. This is a time when diet consists predominantly of liquid, with low solute load, and feeding may be more dependent on issues other than thirst. Indeed, it is not well understood how and when the thirst mechanism develops, presumably sometimes in this first year of life. Nonetheless, as awareness of thirst evolves over time, the risk for severe hyponatremia from excessive free water seems to drop over time.

The variability in clinical severity and age of onset has been proposed to be due to the variable genetic expressivity of the disease [4]. The variability may also relate to other downstream factors, such as aquaporin expression. It may also relate to drinking behaviour and how aggressive parents are with early feeding practices. Our case highlights that even those who present in infancy can lead a relatively normal childhood and reach adult life with minimal symptomatic episodes. It supports previous reports that affected individuals can often self-regulate fluid intake. It also raises the question as to how common this condition might be, since there could be a larger number of genetically affected individuals who remain asymptomatic, or have never had full evaluation.

Regarding treatment, pharmaceutical grade urea was easy to obtain and relatively well tolerated by our patient, despite the unpleasant taste as observed by the mother and others. Effective treatment with oral urea has been described in two other cases of NSIAD, including the original report, and reported in the management of other children with chronic SIADH [6].Subject A was treated with oral urea at dose of $2 \mathrm{~g} / \mathrm{kg} /$ day in 4 divided doses and modest fluid restriction with regular electrolyte monitoring. He maintained generally stable electrolytes, apart from one episode of hyponatremia associated with an intercurrent viral illness in which he did not take his urea well but took extra fluids. In the first 6 months of life, urea levels on treatment were maintained in high normal range. After 10 months of age, dose required no adjustment increase with age, and from 18 months, gradual weaning of dose was undertaken with continuation of modest fluid restriction. Urea treatment was ceased at 19 months of age (16-month treatment) and modest fluid restriction continues at $1500 \mathrm{~mL}$ per day. In another reported case, urea was ceased at age of 10 months (9-month treatment duration) [7] We postulate that the decreased need for urea is most likely commensurate with the development of a reliable thirst mechanism.

Based on current understanding, indications for mutation analysis would be idiopathic SIADH with low or inappropriately normal ADH (5\%-10\% SIADH) [8], family history of hyponatraemia, or SIADH (as was the clue in our case) and perhaps as a part of the investigation panel for poorly defined entities such as exercise-induced hyponatraemia. Once detected, family members can be screened to identify carriers or mildly affected individuals and given advice about the risk of developing symptomatic hyponatremia in the presence of water loading. We were able to advise a maternal family member who was pregnant at the time of mutation studies that she was not a carrier of this mutation and that her child would not be affected. Further elucidation of the genetic variation and delineation of intracellular signalling pathways may reveal wider spectrum of manifestation in this interesting clinical entity.

\section{References}

[1] B. J. Feldman, S. M. Rosenthal, G. A. Vargas, et al., "Nephrogenic syndrome of inappropriate antidiuresis," The New England Journal of Medicine, vol. 352, no. 18, pp. 1884-1890, 2005.

[2] E. Spanakis, E. Milord, and C. Gragnoli, "AVPR2 variants and mutations in nephrogenic diabetes insipidus: review and missense mutation significance," Journal of Cellular Physiology, vol. 217, no. 3, pp. 605-617, 2008.

[3] Y. Tanaka, K. Sugita, T. Saito, et al., "Impaired urinary water excretion in a three-generation family," Pediatric Nephrology, vol. 16, no. 10, pp. 820-822, 2001.

[4] G. Decaux, F. Vandergheynst, Y. Bouko, J. Parma, G. Vassart, and C. Vilain, "Nephrogenic syndrome of inappropriate antidiuresis in adults: high phenotypic variability in men and women from a large pedigree," Journal of the American Society of Nephrology, vol. 18, no. 2, pp. 606-612, 2007.

[5] S. Soule, C. Florkowski, H. Potter, et al., "Intermittent severe, symptomatic hyponatraemia due to the nephrogenic syndrome of inappropriate antidiuresis," Annals of Clinical Biochemistry, vol. 45, no. 5, pp. 520-523, 2008.

[6] E. A. Huang, B. J. Feldman, I. D. Schwartz, D. H. Geller, S. M. Rosenthal, and S. E. Gitelman, "Oral urea for the treatment of chronic syndrome of inappropriate antidiuresis in children," The Journal of Pediatrics, vol. 148, no. 1, pp. 128-131, 2006.

[7] M. A. Marcialis, V. Faà, V. Fanos, et al., "Neonatal onset of nephrogenic syndrome of inappropriate antidiuresis," Pediatric Nephrology, vol. 23, no. 12, pp. 2267-2271, 2008.

[8] G. L. Robertson, "Regulation of arginine vasopressin in the syndrome of inappropriate antidiuresis," The American Journal of Medicine, vol. 119, no. 7, supplement 1, pp. S36-S42, 2006. 